\title{
Testers for combining ability and selection of papaya hybrids resistant to fungal diseases
}

\author{
Marcelo Vivas ${ }^{1 *}$, Silvaldo Felipe da Silveira ${ }^{1}$, Carlos Eduardo Pessanha da Silva Terra ${ }^{1}$ and Messias Gonzaga Pereira ${ }^{2}$
}

Received 10 November 2009

Accepted 10 June 2010

\begin{abstract}
Genetic resistance represents a sustainable alternative to disease control in papaya crop. The purpose of this study was to evaluate the use of testers to estimate combining ability and select hybrids resistant to black spot, phoma spot and chocolate spot. The experiment was conducted in a randomized block design with two replications and 20 plants per plot. The severity of phoma spot and black spot on leaves and the lesion area of black spot and chocolate spot on fruits were evaluated in two seasons. The combining ability of the following crosses is negative for all traits: tester 'JS 12' with 'Sunrise Solo' and 'Kaphoro Solo $P V$ '; tester 'Americano' with 'Caliman M5', 'Sunrise Solo', 'Baixinho de Santa Amália' and 'Waimanalo'; and tester 'Maradol' with 'Caliman G', 'Caliman AM' and 'Sunrise Solo PT'. These results may be useful in breeding for disease resistance by hybridization.
\end{abstract}

Key words: Carica papaya, Asperisporium caricae, Phoma caricae-papayae, Colletotrichum gloeosporioides, specifc combining ability.

\section{INTRODUCTION}

Papaya (Carica papaya L.) may be affected by various diseases, which constitute the main limiting crop factor, requiring adequate control measures that would not cause major damage to production and marketing. Among the diseases that affect the crop stand out black spot, whose causal agent is Asperisporium caricae (Speg.) Maubl. The phoma spot is caused by Phoma caricae-papayae (Tarr) Punith, and anthracnose and chocolate spot share the common etiologic agent Colletotrichum gloeosporioides (Penz.) Penz. \& Sacc. in Penz. (Rezende and Fancelli 1997). The incidence and severity levels of these diseases can be so high that chemical control is a must to achieve profitable production at certain times of the year.
The selection of resistant genotypes is a sustainable alternative to disease control in papaya cultivation. However, total resistance has not been observed in commercial papaya genotypes with some degree of selection. There is, however, the possibility that crosses generate hybrids with higher resistance levels to fungal diseases. Thus, crop breeding can contribute to the selection of resistant genotypes, and/or indicated the best hybrid combinations, based on the hybrid vigor, also known as heterosis.

The hybrid vigor is directly related to the degree of genetic divergence of parents involved (Hallauer and Miranda Filho 1995). However, a high genetic divergence does not necessarily increase the expression of heterosis. It is therefore important to use methods that identify the best combinations (Duarte et al. 2003).

\footnotetext{
${ }^{1}$ Universidade Estadual do Norte Fluminense Darcy Ribeiro (UENF), Laboratório de Entomologia e Fitopatologia, 28.013-600, Campos dos Goytacazes, RJ, Brazil. *E-mail: mrcalvivas@ hotmail.com

${ }^{2}$ Laboratório Melhoramento Genético Vegetal (UENF)
} 
The combining ability analysis provides information about the action of genes associated with a particular trait, as well as for the selection of parents in terms of general combining ability (GCA) and their respective hybrid combinations related to specific combining ability (SCA). The estimation methods of combining ability are quite timeconsuming, particularly for perennial species such as papaya (Dinesh et al. 1995). One possibility is to choose one or more genotypes called testers, which are crossed with all genotypes studied. Then the best combinations for the desired traits are selected.

Different testers can also be used as a criterion of genotype classification into different heterotic groups (Nestares et al. 1999). In breeding programs for high performance with great potential, elite lines are used whenever possible. For this reason, in most cases, the testers used are also elite, by which genotypes with market potential can be obtained, besides a prediction of the performance of potential hybrids (Duarte et al. 2003).

From a practical standpoint, the main purpose of the use of testers is to eliminate poorly performing genotypes from the selection process. In our case, papaya crosses that originated more disease-susceptible progenies would be eliminated. Elias et al. (2000) argue that in this way, the hybrid development program can be streamlined and can be more efficient.

In this sense, this study aims to evaluate testers used in the selection of hybrids resistant to black spot ( $A$. caricae) in leaves and fruits, phoma spot ( $P$. caricaepapayae) on leaves and chocolate spot (C. gloeosporioides) in papaya fruit.

\section{MATERIAL AND METHODS}

Two experiments were conducted on the Fazenda Macuco, of the company Caliman Agrícola S/A, in Linhares, state of Espírito Santo. The first experiment consisted of a group of papaya hybrids from the cross of 20 elite genotypes, 13 of the 'Solo' and seven of the 'Formosa' group, and two testers, 'Sunrise Solo 72/12' ('Solo’ group ) and 'JS 12' ('Formosa' group). The second experiment involved 38 hybrids from the cross of 23 genotypes, 17 of 'Solo' and six of 'Formosa', with three testers of the 'Formosa' group: 'Americano', 'Maradol' and 'Sekati'.

In these two experiments, a randomized block design was used with two replications, 20 plants per plot arranged in double rows, spaced $3.6 \times 2.0 \times 1.8 \mathrm{~m}$, under microsprinkler irrigation. All cultural practices applied were as recommended for the crop. During the development of the experimental crops, fungicides recommended for the crop were sprayed fortnightly to ensure fruit and seed production of the germplasm bank.

Two assessments were performed, the first in late May/early June and the second in late August/early September 2007. The four central plant rows of each plot were evaluated and the plot mean calculated. The disease severity of black and phoma spot on leaves was evaluated as well as the lesion area (percentage) on fruits affected by black and chocolate spot. The leaf severity was determined using a diagrammatic scale developed at the Entomology and Plant Pathology Laboratory, Universidade Estadual do Norte Fluminense Darcy Ribeiro in Campos, Rio de Janeiro. The data of the damaged fruit area were obtained by counting lesions on the external fruit surface (first stage of maturation). The counts were transformed into percentage, by multiplying the number of lesions by the mean values estimated via Quant, corresponding to $0.26 \%$ for black spot and $0.041 \%$ for chocolate spot.

The statistical analysis was performed with SAS software (SAS Institute 1997). The specific combining ability (SCA) was estimated based on the data mean of two evaluation periods. The SCA was calculated by the expression described below, considering the deviation of a single cross from the overall mean of all crosses with a particular tester:

The combining ability was estimated by the expression $S C A=\mu H-\mu T$; where SCA is the specific combining ability; $\mu H$ the mean of a particular combination, and $\mu T$ is the mean of the combinations for a particular tester.

\section{RESULTS AND DISCUSSION}

In the first experiment with testers 'JS 12' and 'Sunrise Solo 72/12', differences were only significant for the trait severity of phoma spot and black spot on fruit, at a probability of $<1 \%$ by the $\mathrm{F}$ test (Table 1 ). In the second experiment, differences were significant for all traits at $1 \%$ probability by the F test (Table 1). Possibly, in combinations with testers 'Americano', 'Maradol' and 'Sekati' the variability for black spot severity on leaves and chocolate spot on fruits was greater, resulting in differences between the hybrids.

\section{Tester 'Sunrise Solo 72/12' ('Solo’ group)}

The severity of $A$. caricae was reduced in all crosses of genotypes with 'Sunrise Solo 72/12'. The best combinations for symptom reduction on leaves and fruits were however 
M Vivas et al.

Table 1. Mean squares of severity of black spot (SBS) and phoma spot (SPS) on leaves and fruit lesion area of black spot (BSF) and chocolate spot (CSF). Estimated values in two sets of papaya hybrids, evaluated two seasons (May/June and August/September 2007)

\begin{tabular}{|c|c|c|c|c|c|}
\hline \multicolumn{6}{|c|}{ Experiment 1} \\
\hline \multirow{2}{*}{ Sources of variation } & \multirow{2}{*}{ df } & \multicolumn{4}{|c|}{ Mean square } \\
\hline & & SBS $^{1}$ & SPS & BSF & CSF \\
\hline Block & 1 & 0.00198 & 0.022781 & 0.35338 & 0.00277 \\
\hline Season $(S)$ & 1 & $0.04579 * *$ & $10.76778^{*}$ & $0.28002 *$ & 0.00029 \\
\hline Genotype (G) & 19 & 0.00043 & $8.71798 * *$ & $0.18266 * *$ & 0.00130 \\
\hline $\mathrm{S} * \mathrm{G}$ & 19 & 0.00023 & 3.92252 & 0.05018 & 0.00126 \\
\hline Error & 39 & 0.00026 & 2.24140 & 0.04633 & 0.00151 \\
\hline \multicolumn{6}{|c|}{ Experiment 2} \\
\hline \multirow{2}{*}{ Sources of variation } & \multirow{2}{*}{ df } & \multicolumn{3}{|c|}{ Mean square } & \\
\hline & & SBS $^{1}$ & SPS & BSF & CSF \\
\hline Block & 1 & 0.00031 & 0.38804 & 0.08526 & 0.00269 \\
\hline Season (S) & 1 & $0.04725^{* *}$ & 3.64560 & $0.20338 * *$ & $0.07427 * *$ \\
\hline Genotype (G) & 37 & $0.00067^{* *}$ & $12.89296^{* *}$ & $0.06847 * *$ & $0.01042 * *$ \\
\hline $\mathrm{S}^{*} \mathrm{G}$ & 37 & 0.00036 & 7.48510 & 0.02373 & $0.00878^{*}$ \\
\hline Error & 75 & 0.00029 & 5.14661 & 0.01846 & 0.00542 \\
\hline
\end{tabular}

* Significant at $5 \% ; * *$ Significant at $1 \%$ by the $\mathrm{F}$ test.

${ }^{1}$ SBS - Severity of black spot on leaves, SPS - Severity of phoma spot on leaves, BSF - fruit lesion area of black spot and CSF - fruit lesion area of chocolate spot.

not identified. For the lesion area on fruits affected by black spot, the best combinations, i.e., those with negative SCA values, included the genotypes 'Costa Rica', 'Tailândia', 'Mamão Bené', 'Mamão Roxo', and 'Sekati'. For black spot severity on leaves, the genotypes 'Mamão Bené', 'Mamão Roxo', 'Maradol' and 'Maradol GL' originated hybrids with negative SCA estimates in crosses with the tester in question (Table 2).

In the crosses with 'Tailândia', 'Maradol' and 'Maradol GL' and 'Sekati' the SCA values for severity of phoma spot were negative, in other words, these hybrids can be used to reduce $P$. caricae-papayae severity.

For chocolate spot symptoms on fruit, the only genotype with a positive SCA value was obtained in a cross of the tester 'Sunrise Solo 72/12' with 'Maradol GL'; the other genotypes generated hybrids with negative and low mean SCA values for lesion area of C. gloeosporioides on fruits.

\section{Tester 'JS 12' ('Formosa' group)}

Of the 13 genotypes crossed with tester 'JS 12', the SCA values were negative for at least one trait in all hybrids but not to the combination involving 'Caliman $G$ ' (Table 2). The insertion height of the first fruit of this cross was high and it produced more fruits with higher weight than other hybrids, resulting in high-yielding plants (Ide et al. 2009). However, the values of soluble solids and fruit firmness were low (Ide et al. 2009).

Considering the variables related to $A$. caricae resistance, i.e., low SCA mean values, the best combinations of this tester were with 'Sunrise Solo', 'Grampola', 'Diva', 'Taiwan et', 'Kapoho Solo PV' and 'Solo Kapoho PA' for black spot severity on leaves. For fruit lesion area of black spot, the best combinations involved Kapoho Solo PV', 'Caliman SG', 'Baixinho de Santa Amália' (BSA), 'Sunrise Solo PT', 'Grampola', 'Caliman M5' and 'Sunrise Solo'.

The means for fruit lesion areas of chocolate spot were zero in the crosses of tester 'JS 12' with the genotypes 'Taiwan et' and 'Sunrise Solo PT'. Besides, the SCA values for fruit lesion areas of chocolate spot were also negative in theses combinations. The genotypes 'BSA', 'Caliman M5', 'Diva', 'Sunrise Solo' and 'Kapoho Solo PV' can also be cited for use in crosses with 'JS 12' to reduce the fruit lesion area caused by $C$. gloeosporioides.

For the two fruit-related variables fruit lesion area of black spot and chocolate spot, the SCC values of the genotypes 'BSA', 'Caliman M5', 'Sunrise Solo', 'Kapoho Solo PV' and 'Sunrise Solo PT' were negative in both cases, which may contribute to a reduction of the fruit lesion 
Table 2. Mean values and specific combining ability (SCA) of severity of phoma spot (SPS) and black spot (SBS) on leaves, and fruit lesion area of black spot (BSF) and chocolate spot (CSF) in hybrids of experiment 01, consisting of 20 genotypes, 13 of group 'Solo' and seven of group 'Formosa', crossed with two testers ('Sunrise Solo 72/12' - group 'Solo' and 'JS 12' - group 'Formosa')

\begin{tabular}{|c|c|c|c|c|c|c|c|c|c|}
\hline \multirow{2}{*}{ Tester } & \multirow{2}{*}{$\begin{array}{c}\text { Parents 'Solo' and } \\
\text { 'Formosa' }\end{array}$} & \multicolumn{2}{|c|}{ SBS } & \multicolumn{2}{|c|}{ SPS } & \multicolumn{2}{|c|}{ BSF } & \multicolumn{2}{|c|}{ CSF } \\
\hline & & Mean & SCA & Mean & SCA & Mean & SCA & Mean & SCA \\
\hline \multirow{7}{*}{ 'SS 72/12' } & 'Costa Rica' & 0.036 & 0.003 & 8.706 & 3.488 & 0.098 & -0.127 & 0.018 & -0.001 \\
\hline & 'Tailândia' & 0.045 & 0.011 & 4.225 & -0.993 & 0.222 & -0.004 & 0.013 & -0.006 \\
\hline & 'Mamão Bené' & 0.031 & -0.003 & 7.363 & 2.145 & 0.173 & -0.053 & 0.000 & -0.018 \\
\hline & 'Mamão Roxo' & 0.017 & -0.016 & 5.513 & 0.295 & 0.103 & -0.123 & 0.013 & -0.006 \\
\hline & 'Maradol' & 0.025 & -0.008 & 2.563 & -2.655 & 0.426 & 0.199 & 0.013 & -0.006 \\
\hline & 'Maradol GL' & 0.033 & -0.003 & 3.694 & -1.524 & 0.261 & 0.035 & 0.048 & 0.029 \\
\hline & 'Sekati' & 0.052 & 0.019 & 3.869 & -1.349 & 0.144 & -0.082 & 0.005 & -0.013 \\
\hline \multirow{13}{*}{ 'JS 12' } & 'Caliman M5' & 0.048 & 0.002 & 3.988 & -1.037 & 0.479 & -0.018 & 0.008 & -0.009 \\
\hline & 'Taiwan et' & 0.043 & -0.004 & 5.750 & 0.725 & 0.510 & 0.012 & 0.000 & -0.017 \\
\hline & 'Diva' & 0.041 & -0.005 & 3.656 & -1.369 & 0.551 & 0.052 & 0.008 & -0.009 \\
\hline & 'Grampola' & 0.036 & -0.006 & 4.681 & -0.318 & 0.499 & -0.049 & 0.018 & 0.005 \\
\hline & 'Sunrise Solo' & 0.033 & -0.014 & 3.875 & -1.150 & 0.483 & -0.016 & 0.010 & -0.007 \\
\hline & 'Caliman GB' & 0.048 & 0.001 & 5.081 & 0.056 & 0.836 & 0.339 & 0.038 & 0.021 \\
\hline & 'Caliman SG' & 0.047 & 0.002 & 7.044 & 2.022 & 0.317 & -0.196 & 0.073 & 0.059 \\
\hline & 'Caliman G' & 0.047 & 0.005 & 5.375 & -0.487 & 0.662 & 0.213 & 0.020 & 0.008 \\
\hline & 'Kapoho Solo PA' & 0.046 & -0.001 & 5.956 & 0.931 & 0.673 & 0.176 & 0.023 & 0.006 \\
\hline & 'BSA' & 0.061 & 0.015 & 5.256 & 0.231 & 0.337 & -0.160 & 0.003 & -0.014 \\
\hline & 'São Mateus' & 0.050 & 0.004 & 4.694 & -0.285 & 0.724 & 0.214 & 0.027 & 0.007 \\
\hline & 'Kapoho Solo' PV' & 0.044 & -0.002 & 4.831 & -0.194 & 0.294 & -0.206 & 0.013 & -0.004 \\
\hline & 'Sunrise Solo' PT' & 0.050 & 0.004 & 3.544 & -1.481 & 0.360 & -0.137 & 0.000 & -0.017 \\
\hline
\end{tabular}

area by the fungi $A$. caricae and $C$. gloeosporioides in combinations with 'JS 12'.

Ide et al. (2009) found that crosses between 'JS 12' and genotype 'São Mateus' can be used in selection due to the good morphological, yield and quality traits. The SCA values of this cross were also low for phoma spot severity and may be used to reduce the severity of $P$. caricae papayae on leaves. This combination was however not significant for the other traits. Aside from 'São Mateus', other genotypes seemed promising, with low SCA values for phoma spot severity: 'Sunrise Solo PT', 'Diva', 'Sunrise Solo', 'Caliman M5', 'Caliman G', 'Grampola', and 'Kapoho Solo PV'.

\section{Tester 'Americano' ('Formosa' group)}

Based on the specific combining ability (SCA) estimated for the parent genotypes of 20 hybrids involving tester 'Americano', the SCA values of 'Caliman M5', 'Sunrise Solo', Baixinho de Santa Amália' and 'Waimanalo' were negative for the variables related to the severity reduction of black spot on leaves and fruits, and of phoma spot on leaves and chocolate spot on fruit (Table 3).

Besides the hybrids derived from the above genotypes, 'Sunrise Solo 783', 'Diva', 'Grampola', 'Caliman AM', 'Caliman GB', 'Sunrise Solo PT', and 'Baixinho super' also produced hybrids with low mean values of $A$. caricae severity on leaves, when crossed with tester 'Americano'.

For severity of phoma spot on leaves, crosses of 'Americano' with 'Caliman M5', 'Sunrise Solo 783', 'Costa Rica', 'Sunrise Solo', 'Caliman AM', 'BSA' , 'Sunrise Solo TJ', 'Matthew', 'Mamão Roxo', and 'Waimanalo' performed well. For genotype 'Waimanalo', Marin et al. (2006) observed a trend to a major genetic contribution to higher fruit weight. 'Sunrise Solo TJ' and 'Sunrise Solo 783' tended to increase the total yield.

For traits related to fruit quality, Marin et al. (2006) verified a greater contribution of the genotypes 'JS 11', 'JS 12', 'BSA' flesh taste. Of these genotypes, the SCA values of 'BSA' crossed with 'Americano' were lower for fruit lesion area by black spot and by chocolate spot, 
M Vivas et al.

Table 3. Mean values and specific combining ability (SCA) of severity of phoma spot (SPS) and black spot (SBS) on leaves, and fruit lesion area of black spot (BSF) and chocolate spot (CSF) in hybrids of experiment 2, consisting of different papaya genotypes crossed with testers 'Americano', 'Maradol' and 'Sekati', of the group 'Formosa'

\begin{tabular}{|c|c|c|c|c|c|c|c|c|c|}
\hline \multirow{2}{*}{ Tester } & \multirow{2}{*}{$\begin{array}{c}\text { Parents 'Solo' and } \\
\text { 'Formosa' }\end{array}$} & \multicolumn{2}{|c|}{ SBS } & \multicolumn{2}{|c|}{ SPS } & \multicolumn{2}{|c|}{ BSF } & \multicolumn{2}{|c|}{ CSF } \\
\hline & & Mean & SCA & Mean & SCA & Mean & $\overline{\text { SCA }}$ & Mean & SCA \\
\hline \multirow{20}{*}{ 'Americano' } & 'Caliman M5' & 0.027 & -0.001 & 5.394 & -0.912 & 0.207 & -0.009 & 0.000 & -0.013 \\
\hline & 'SS 783' & 0.027 & -0.001 & 5.400 & -0.906 & 0.246 & 0.030 & 0.011 & -0.003 \\
\hline & 'Costa Rica' & 0.036 & 0.008 & 5.875 & -0.431 & 0.209 & -0.007 & 0.000 & -0.013 \\
\hline & 'Diva' & 0.026 & -0.003 & 7.356 & 1.050 & 0.272 & 0.056 & 0.000 & -0.013 \\
\hline & 'Grampola' & 0.020 & -0.008 & 9.063 & 2.757 & 0.321 & 0.104 & 0.000 & -0.013 \\
\hline & 'Sunrise Solo' & 0.025 & -0.003 & 5.363 & -0.943 & 0.079 & -0.140 & 0.000 & -0.013 \\
\hline & 'Caliman AM' & 0.024 & -0.004 & 5.150 & -1.156 & 0.161 & -0.055 & 0.066 & 0.052 \\
\hline & 'Caliman GB' & 0.024 & -0.004 & 7.444 & 1.138 & 0.196 & -0.021 & 0.003 & -0.011 \\
\hline & 'Caliman SG' & 0.034 & 0.006 & 7.613 & 1.307 & 0.320 & 0.102 & 0.008 & -0.006 \\
\hline & 'Caliman G' & 0.035 & 0.007 & 7.313 & 1.007 & 0.233 & 0.017 & 0.142 & 0.129 \\
\hline & 'BSA' & 0.021 & -0.007 & 5.219 & -1.087 & 0.150 & -0.066 & 0.000 & -0.013 \\
\hline & 'Sunrise Solo TJ' & 0.040 & 0.011 & 6.225 & -0.081 & 0.424 & 0.208 & 0.021 & 0.007 \\
\hline & ‘São Mateus' & 0.030 & 0.002 & 4.769 & -1.537 & 0.069 & -0.148 & 0.003 & -0.011 \\
\hline & 'Kapoho Solo PV' & 0.029 & 0.001 & 8.344 & 2.038 & 0.336 & 0.118 & 0.005 & -0.008 \\
\hline & 'Sunrise Solo PT' & 0.027 & -0.001 & 6.613 & 0.307 & 0.220 & 0.004 & 0.000 & -0.013 \\
\hline & 'Mamão Roxo' & 0.033 & 0.005 & 5.081 & -1.225 & 0.210 & -0.006 & 0.003 & -0.011 \\
\hline & ‘Sekati' & 0.031 & 0.002 & 7.750 & 1.444 & 0.051 & -0.164 & 0.000 & -0.013 \\
\hline & 'Baixinho Super' & 0.025 & -0.003 & 6.844 & 0.538 & 0.303 & 0.087 & 0.000 & -0.013 \\
\hline & 'STZ-52' & 0.041 & 0.013 & 6.394 & 0.088 & 0.248 & 0.032 & 0.005 & -0.008 \\
\hline & 'Waimanalo' & 0.008 & -0.020 & 2.906 & -3.400 & 0.075 & -0.142 & 0.000 & -0.013 \\
\hline \multirow{9}{*}{ 'Maradol' } & 'Caliman G' & 0.031 & -0.001 & 2.656 & -0.777 & 0.108 & -0.149 & 0.008 & -0.057 \\
\hline & 'Caliman AM' & 0.020 & -0.011 & 3.100 & -0.333 & 0.158 & -0.100 & 0.021 & -0.044 \\
\hline & 'Caliman SG' & 0.042 & 0.011 & 2.894 & -0.539 & 0.465 & 0.207 & 0.165 & 0.100 \\
\hline & 'Sunrise Solo' & 0.024 & -0.007 & 3.931 & 0.498 & 0.251 & -0.008 & 0.216 & 0.152 \\
\hline & 'Diva' & 0.030 & -0.002 & 3.719 & 0.286 & 0.675 & 0.417 & 0.084 & 0.020 \\
\hline & 'SS 72/12' & 0.032 & 0.000 & 4.344 & 0.911 & 0.140 & -0.118 & 0.026 & -0.039 \\
\hline & 'Caliman M5' & 0.063 & 0.031 & 3.531 & 0.098 & 0.215 & -0.042 & 0.051 & -0.014 \\
\hline & 'Sunrise Solo PT' & 0.023 & -0.008 & 3.288 & -0.145 & 0.251 & -0.006 & 0.008 & -0.057 \\
\hline & JS 12' & 0.039 & -0.013 & 2.319 & 0.005 & 0.215 & -0.200 & 0.115 & -0.062 \\
\hline \multirow{9}{*}{ 'Sekati' } & 'Caliman G' & 0.028 & -0.017 & 4.013 & 0.117 & 0.098 & -0.006 & 0.023 & 0.003 \\
\hline & 'Calim an AM' & 0.065 & 0.020 & 1.850 & -2.046 & 0.070 & -0.029 & 0.003 & -0.017 \\
\hline & 'Caliman SG' & 0.044 & 0.000 & 3.719 & -0.177 & 0.059 & -0.045 & 0.005 & -0.014 \\
\hline & 'Caliman GB' & 0.031 & -0.014 & 4.681 & 0.785 & 0.111 & 0.006 & 0.000 & -0.019 \\
\hline & 'Sunrise Solo' & 0.038 & -0.007 & 4.638 & 0.742 & 0.070 & -0.034 & 0.000 & -0.019 \\
\hline & 'Diva' & 0.034 & -0.011 & 4.031 & 0.135 & 0.122 & 0.018 & 0.021 & 0.001 \\
\hline & 'Caliman M5' & 0.051 & 0.006 & 5.356 & 1.460 & 0.036 & -0.067 & 0.008 & -0.012 \\
\hline & 'JS 11' & 0.018 & 0.029 & 3.438 & 0.560 & 0.057 & 0.046 & 0.003 & -0.019 \\
\hline & 'JS 12' & 0.073 & -0.005 & 5.069 & -1.577 & 0.150 & 0.112 & 0.000 & 0.095 \\
\hline
\end{tabular}


indicating higher post-harvest quality. Apart from 'BSA', the SCA values of hybrids from crosses of 'Americano' with the genotypes 'Caliman M5', 'Costa Rica', 'Diva', 'Grampola', 'Sunrise Solo', 'Sunrise Solo PT', 'Sekati', 'Baixinho Super', and 'Waimanalo' were negative for fruit lesion area by chocolate spot and showed no symptoms of this disease.

\section{Tester 'Maradol' ('Formosa1 group)}

Of the nine crosses involving tester 'Maradol', three parental genotypes produced hybrids with negative SCA for the study variables (Table 3), ie., 'Caliman G', 'Caliman AM' and 'Sunrise Solo PT' crossed with 'Maradol' tended to produce hybrids with low severity of $A$. caricae, $P$. caricae-papayae and C.gloeosporioides.

For the trait severity of phoma spot (P. caricaepapayae) on leaves, aside from the three genotypes mentioned above, the combination 'Maradol x Caliman SG' is also noteworthy, with negative SCA values and likely to produce hybrids with low values of this variable.

With regard to the fungus $A$. caricae, low SCA was observed in all hybrids but of three parent genotypes for black spot severity on leaves and of two for fruit lesions by black spot. Analyzing the two variables together, the SCA estimates of crosses of 'Maradol' with the genotypes 'Caliman G', 'Caliman AM', 'Sunrise Solo' and 'Sunrise Solo PT' were negative for both variables.

Hybrids from crosses of 'Maradol' with the genotypes 'Caliman G', 'Caliman AM', 'Sunrise Solo 72/12', 'Caliman M5', Sunrise Solo PT', and 'JS 12' tended to negative SCA values and may contribute to the generation of hybrids with reduced fruit lesion area of chocolate spot.

Marin et al. (2006) evaluated the hybrids in a partial diallel scheme and concluded that the genotype 'Maradol' tended to a strong genetic contribution to increased fruit weight, while 'Sunrise Solo 72 /12' may be used to obtain hybrids with lower weight. They also stated that the genotypes 'Maradol', 'Cariflora', 'Sunrise Solo 783' and 'Sunrise Solo TJ' would tend most to increase the total yield.

\section{Tester 'Sekati' ('Formosa' group)}

Of the nine genotypes tested with 'Sekati', five produced hybrids with negative SCA values for black spot severity on leaves: 'Caliman G', 'Caliman GB', 'Sunrise Solo', 'Diva', and 'JS 12'. For fruit lesion area by black spot, 'Sunrise Solo' and variations of 'Caliman' (G, AM,
SG, and M5) performed best, all with negative SCA values and tendency to generate hybrids with low mean disease severity values (Table 3 ).

Considering the severity of phoma spot on leaves, the genotypes 'Caliman AM', 'Caliman SG' and 'JS 12' crossed with 'Sekati' resulted in hybrids with the best SCA values. Marim et al. (2006) evaluated traits related to fruit quality and identified a greater contribution to reduced ovarian cavity, increased soluble solids content and improved flesh taste in the genotypes 'JS 11', 'JS 12', 'Baixinho de Santa Amália', and 'Tailândia'.

Based on the SCA estimates and hybrid means of the cross of 'JS 12' with 'Sekati' it was concluded that SCA was negative for the severity of $A$. caricae and $P$. caricae-papayae on leaves, indicating the usefulness to reduce the severity of these pathogens on papaya leaves (Table 3). Hybrids from crosses of 'Sekati' with genotype 'JS 11' however had a low mean area of fruit lesions caused by chocolate spot and negative SCA for this trait. The genotypes 'Baixinho de Santa Amália' and 'Tailândia' were not crossed with 'Sekati' in this experiment.

Genotypes crossed with tester 'Sekati', 'Caliman G', 'Sunrise Solo' and 'JS 12' originated hybrids free of chocolate spot symptoms and with negative SCA estimates. Aside from these, the SCA values of 'Caliman AM', 'Caliman SG', 'Caliman M5', and 'JS 11' were lowest.

In the literature only the study of Ide et al. (2009) investigated the combining ability for papaya by testers. This is the first study on the combining ability of papaya genotypes for resistance to $A$. caricae, $P$. caricaepapayae and to $C$. gloeosporioides. The plant and fruit quality traits were evaluated elsewhere.

Marin et al. (2006) used a partial diallel scheme to combine eight papaya varieties of the 'Formosa' with eight of the 'Solo' group. Among other traits, the number of fruits, fruit weight, plant height, total soluble solids and flesh taste were evaluated. The general combining ability (GCA) for the varieties 'Maradol' and 'Cariflora' of 'Formosa' and 'Sunrise Solo 783' and 'Sunrise Solo TJ', of the 'Solo' group, was highest for yield, while the specific combining ability (SCA) for the traits was highest in the hybrid combinations: 'Sunrise Solo 72/12× JS 12', 'Sunrise Solo TJ $\times$ JS 12', 'Baixinho de Santa Amália $\times$ JS 12', 'Sunrise Solo $\times$ JS 11', and 'Sunrise Solo 72/12 × Costa Rica'.

This study can guide breeding for the establishment of hybrids with lower levels of black spot on leaves and fruits, of phoma spot on leaves and chocolate spot on fruits, 
M Vivas et al.

as well as provide information on quality traits of plant and fruit and on resistance to diseases.

\section{ACKNOWLEDGEMENTS}

The authors wish to thank the Financiadora de Estudos e Projetos (FINEP), the Universidade Estadual do Norte Fluminense Darcy Ribeiro (UENF) and the company Caliman Agrícola S/A for financial and logistical support.

\title{
Testadores para capacidade combinatória e seleção de híbridos de mamoeiro resistentes a doenças fúngicas
}

\begin{abstract}
RESUMO - A resistência genética constitui alternativa sustentável para o controle de doenças na cultura do mamoeiro. O objetivo do presente estudo foi avaliar o uso de testadores na estimação da capacidade combinatória e na seleção de híbridos com resistência à pinta-preta, mancha-de-phoma e mancha-chocolate. O experimento foi conduzido em blocos ao acaso, com duas repetições de vinte plantas por parcela. Avaliou-se, em duas épocas, a severidade de mancha-de-phoma e pinta-preta em folhas, $e$ área do fruto lesionada por pinta-preta e mancha-chocolate. Os híbridos com valores negativos de capacidade combinatória para todas as características avaliadas derivaram do cruzamento do testador 'JS 12' com 'Sunrise Solo' e 'Kapoho Solo PV', do testador 'Americano' com 'Caliman M5', 'Sunrise Solo', 'Baixinho de Santa Amália' e 'Waimanalo' e do testador 'Maradol' com 'Caliman G', 'Caliman AM' e 'Sunrise Solo PT'. Estes resultados orientarão o melhoramento voltado para a resistência às doenças por meio de hibridizações.
\end{abstract}

Palavras-chave: Carica papaya, Asperisporium caricae, Phoma caricae-papayae, Colletotrichum gloeosporioides, capacidade específica de combinação.

\section{REFERENCES}

Dinesh MMR, Ramachander PR, Iyer CPA and Subramanyam MD (1995) Mean performance of parent means to predict general combining ability effect in papaya (Carica papaya L.). Acta Horticulturae 394: 337-345.

Duarte IA, Ferreira JM and Nuss CN (2003) Potencial discriminatório de três testadores em "topcrosses" de milho. Pesquisa Agropecuária Brasileira 38: 365-372.

Elias HT, Carvalho SP and André CGM (2000) Comparações de testadores na avaliação de famílias s1 de milho. Pesquisa Agropecuária Brasileira 35: 1135-1142.

Ide CD, Pereira MG, Viana AP and Pereira TNS (2009) Use of testers for combining ability and selection of papaya hybrids. Crop Breeding and Applied Biotechnology 9: 60-66.
Hallauer AR and Miranda Filho JB (1995) Quantitative genetics in maize breeding. $2^{\text {nd }}$ ed., Iowa State University Press, Ames, $468 \mathrm{p}$.

Marin SLD, Pereira MG, Amaral Junior AT, Martelleto LAP and Ide CD (2006) Partial diallel to evaluate the combining ability for economically important traits of papaya. Scientia Agricola 63: $540-546$.

Nestares G, Frutos E and Eyhérabide G (1999) Evaluación de líneas de maíz flint colorado por amplitud combinatoria. Pesquisa Agropecuária Brasileira 34: 1399-1406.

Rezende JAM and Fancelli MI (1997) Doenças do mamoeiro (Carica papaya L.). In Kimati H, Amorim L, Bergamin Filho A, Camargo LEA and Rezende JAM (ed.) Manual de fitopatologia. Doenças das plantas cultivadas. Agronômica Ceres, São Paulo, p. 486-496.

SAS Institute (1997) SAS/STAT software: changes and enhancements through release 6.12. Statistical Analysis System Institute, Cary, $1167 \mathrm{p}$. 